\title{
Fermentation enhances the antioxidant and anti-inflammatory effects of Bat Faeces (Ye Ming Sha) via the ERK, p38 MAPK and NF- $\kappa$ B signaling pathways in RAW 264.7 cells
}

\author{
Han-Saem Lee ${ }^{1} \cdot$ So-Hyun Chon ${ }^{1} \cdot$ Min-A Kim ${ }^{1} \cdot$ Jeong-Eun Park ${ }^{1} \cdot$ Yu-Mi Lim ${ }^{1}$. \\ Eun-Jeong Kim ${ }^{1} \cdot$ Eun-Kyung Son ${ }^{1} \cdot$ Sang-Jun Kim ${ }^{2} \cdot$ Jai-Hyun So $^{1}$ (D)
}

Received: 3 December 2018 / Accepted: 14 January 2019 / Published Online: 31 March 2019

(C) The Korean Society for Applied Biological Chemistry 2019

\begin{abstract}
The ethyl acetate fraction of Bat Faeces (Ye Ming Sha: natural products used in Chinese Medicine) after fermentation (EFBF-AF) showed enhanced anti-oxidative effects in 2,2-diphenyl1-picrylhydrazyl and 2,2'-azino-bis(3-ethylbenzothiazoline-6sulfonic acid) diammonium salt assays. Fermentation of the Bat Faeces by using the crude enzyme extract from Aspergillus kawachii, significantly increased the anti-inflammatory effects. Fermented Bat Faeces markedly inhibited nitric oxide production, inducible nitric oxide synthase, and cyclooxygenase-2 expression in lipopolysaccharide (LPS)-stimulated RAW 264.7 macrophage cells. The EFBF-AF reduced the nuclear translocation of nuclear factor kappa B (NF- $\kappa \mathrm{B})$ via IKK $\alpha$ and I $\mathrm{B} \alpha$ phosphorylation, and decreased the phosphorylated the extracellular signal-regulated kinases (ERK) and p38 expression in LPS-treated RAW 264.7 macrophages. In addition, the EFBF-AF suppressed the expression of pro-inflammatory genes, such as interleukin- $1 \beta$, interleukin-6, and tumor necrosis factor- $\alpha$. These results suggest that fermented Bat Faeces may suppress pro-inflammatory responses in LPSstimulated RAW 264.7 macrophages cells via ERK, p38 mitogenactivated protein kinase and NF- $\mathrm{KB}$ signaling pathways.
\end{abstract}

Keywords Anti-inflammatory effect · Antioxidative effect

Jai-Hyun So $(\bowtie)$

E-mail: dukeny@nikom.or.kr

${ }^{1}$ National Development Institute of Korean Medicine, 94, Hwarang-ro, Gyeongsan, Gyeongbuk 38540, Republic of Korea

${ }^{2}$ Department of Natural Science, Republic of Korea Naval Academy, Gyeongnam 645-797, Republic of Korea

This is an Open Access article distributed under the terms of the Creative Commons Attribution Non-Commercial License (http://creativecommons. org/licenses/by-nc/3.0/) which permits unrestricted non-commercial use, distribution, and reproduction in any medium, provided the original work is properly cited.
Aspergillus kawachii · Bat Faeces · Fermentation · Vespertilio superans Thomas

\section{Introduction}

Bat Faeces (Vespertilio superans Thomas), Ye Ming Sha, is one of the natural products used in Chinese medicine [1]. The other natural products used by Chinese medical practitioners include plants, minerals and animal substances [2]. Bat Faeces is a coarse powder, dark brown in color, resembles tea-dust in appearance, and includes debris of the Mylabris insect, Bat dung, dirt, and other extraneous substances. Bat dung is popularly referred to as night-bright sand. It is used in the treatment of chronic eye diseases in China [3].

Reactive oxygen species (ROS) is classified into two categories. The first category includes the oxygen radicals such as alkoxy $\left(\mathrm{RO}^{\circ}\right)$, superoxide anion $\left(\mathrm{O}_{2}{ }^{-}\right)$, peroxy ( $\left.\mathrm{ROO}\right)$, hydroxy $\left(\mathrm{HO}^{\circ}\right)$, and hydroperoxy $\left(\mathrm{HOO}^{\circ}\right)$ radicals. Non-radical derivatives of oxygen including hydrogen peroxide $\left(\mathrm{H}_{2} \mathrm{O}_{2}\right)$, ozone $\left(\mathrm{O}_{3}\right)$, and singlet oxygen $\left({ }^{1} \mathrm{O}_{2}\right)$ from the second category [4]. Excess production of ROS in body results in many biological changes, such as ageing, DNA damage, heart disease and cancer [5]. Antioxidants help to protect the body against damage caused by ROS. Medicinal plants and other natural substances have gained much interest in the recent times as sources of biologically active substances such as antioxidants, antimutagens, and anticarcinogens [6]. Inflammation is one of the defensive reactions of living tissues to physical damage, toxic substances and external chemical stimuli [7]. In murine RAW 264.7 cells, an innate immune response may involve recognition of lipopolysaccharide (LPS) by the Toll like receptor 4 (TLR4) and activation of NF- $\kappa B$ [8]. Exposure to LPS leads to increased expression of inducible nitric 
oxide synthase (iNOS) and cyclooxygenase-2 (COX-2), which in turn increases the levels of nitric oxide (NO) resulting in inflammation $[9,10]$. NF- $\kappa B$ activation and signaling play a central role, releasing inflammatory cytokines such as interleukin$1 \beta$ (IL-1 $\beta$ ), interleukin-6 (IL-6) and tumor necrosis factor- $\alpha$ (TNF- $\alpha$ ) in LPS-induced inflammatory RAW 264.7 cells $[11,12]$. Phosphorylation of the mitogen-activated protein kinases (MAPKs) is also associated with inflammatory responses including mitosis, differentiation, and cell survival/apoptosis [13].

Fermentation is one of the commonly used food processing techniques for increasing the flavor or fragrance [14]. Further, it is used as a method for increasing the content of the physiologically active substances. For example, fermentation of licorice (crude enzyme treatment) increased the content of liquiritigenin which has anti-oxidant, anti-dementia, and anti-microbial activities [15]. Another example is the enhancement of the active form of quercetin in onion by enzyme treatment. Bioavailability and physiological activity of quercetin are very low in onion, because quercetin mostly exists in the glycoside form in combination with glucose. $\beta$-Glycosidase treatment enhances the antioxidant activity by increasing the active quercetin content in onion [16].

Based on this background knowledge, we attempted to improve the anti-oxidant and anti-inflammatory activities of Bat Faeces by fermentation. In addition, we investigated whether the ethyl acetate fraction of Bat Faeces after fermentation (EFBF-AF) increase inhibition of the inflammatory response such as NF- $\mathrm{B}$ activation and phosphorylation of ERK and p38 in LPS-stimulated RAW 264.7 cells.

\section{Materials and Methods}

\section{Chemicals}

Extraction solvents, including methanol $(\mathrm{MeOH})$, ethanol (EtOH), $n$-hexane (hexane), ethyl acetate (EtOAc) and $n$-butanol $(\mathrm{BuOH})$ were purchased from Duksan Chemical Co. (Seoul, Korea). Chemical reagents such as 2,2-diphenyl-1-picrylhydrazyl (DPPH), 2,2'-azino-bis(3-ethylbenzothiazoline-6-sulfonic acid) diammonium salt (ABTS), potassium persulfate, 3-(4,5-dimethylthiazol-2-yl)2,5-diphenyltetrazolium bromide (MTT) and LPS (Escherichia coli 0111:B4) were purchased from Sigma Chemical Co. (St. Louis, MO, USA). Primary antibodies for iNOS, NF- $\kappa B, \beta$-actin,

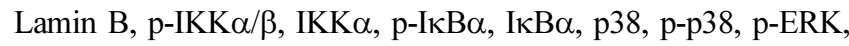
and ERK were purchased from Cell Signaling Technology Inc. (Boston, MA, USA) and COX-2 antibodies were purchased from Abcam (Cambridge, MA, USA). Horseradish peroxidase (HRP)conjugated secondary antibodies were purchased from Santa Cruz Biotechnology (Santa Cruz, CA, USA).

Bat Faeces and preparation of Aspergillus kawachii enzyme extract

Bat Faeces (500 g), purchased from Daegu Oriental Medicine
Market, in Korea was refluxed two times with $3.5 \mathrm{~L}$ of $70 \%$ $\mathrm{MeOH}$ for $3 \mathrm{~h}$. The extract was filtered through the filter paper and concentrated using Rotary evaporator. Crude enzyme extract was prepared from the soybean paste fungi, Aspergillus kawachii, according to the previous report with some modification [16]. Ten grams of wheat bran in $10 \mathrm{~mL}$ of distilled water was sterilized at $121{ }^{\circ} \mathrm{C}$ for $30 \mathrm{~min}$. A. kawachii grown in potato dextrose agar media (Difco Laboratories, Detroit, MI, USA) was inoculated into the sterilized wheat bran and incubated at $30^{\circ} \mathrm{C}$ for 3 days. Incubated wheat bran was suspended in $100 \mathrm{~mL}$ of $100 \mathrm{mM}$ sodium phosphate buffer ( $\mathrm{pH} 7.0)$ and kept at $4{ }^{\circ} \mathrm{C}$ for $18 \mathrm{~h}$. The reaction mixture was then centrifuged at $10,000 \mathrm{rpm}$ for $15 \mathrm{~min}$. The supernatant was used for the fermentation of Bat Faeces. This solution contained $0.276 \mathrm{U} / \mathrm{mL}$ ( $1 \mathrm{U}$ is defined as the enzyme activity needed to produce $1 \mu \mathrm{mol}$ of $\mathrm{p}$-nitrophenol from $\mathrm{p}$ nitrophenyl- $\beta$-D-glucopyranoside per min) of $\beta$-glucosidase activity.

\section{Fermentation of Bat Faeces}

The methanol extract of the Bat Faeces was re-suspended in 200 $\mathrm{mL}$ of distilled water and $100 \mathrm{~mL}$ aliquot of this suspension was treated with $100 \mathrm{~mL}$ of active or inactive crude enzyme extract. The mixture was incubated with shaking at $100 \mathrm{rpm}$ at $30^{\circ} \mathrm{C}[16]$. After $18 \mathrm{~h}$, the reaction mixture was partitioned sequentially in three different solvents, hexane, EtOAc and $\mathrm{BuOH}$. Inactive crude enzyme was prepared by autoclaving at $121{ }^{\circ} \mathrm{C}$ for $30 \mathrm{~min}$, served as the control.

\section{UPLC conditions for fermentation of Bat Faeces}

The UPLC was performed to compare changing compounds during the fermentation. The fermented Bat Faeces were quantified by Acquity ${ }^{\mathrm{TM}}$ Ultraperformance LC system (UPLC, Waters, Milford, MA, USA) with the wavelength set at $280 \mathrm{~nm}$. The UPLC analyses were performed using a ACQUITY UPLC CSH C18 $(2.1 \times 100 \mathrm{~mm}, 1.7 \mu \mathrm{m}$; Waters, Milford, USA $)$ reverse phase column and the and the mobile phase consisted of water (solvent A) and acetonitrile (solvent B) each containing $0.1 \%$ formic acid. After $2 \mu \mathrm{L}$ of the sample was injected into the column, solvent B increased from $0 \%$ to $100 \%$ in $9 \mathrm{~min}$, held at $100 \%$ for $1 \mathrm{~min}$. The solvent flow rate was $0.3 \mathrm{~mL} / \mathrm{min}$.

\section{DPPH radical scavenging assay}

The DPPH assay was performed according to a method described by Yoshiki [17] with some modifications. DPPH $(150 \mu \mathrm{M}$ in $\mathrm{EtOH}, 190 \mu \mathrm{L}$ ) was mixed with samples in dimethyl sulfoxide (DMSO, $10 \mu \mathrm{L})$ at different concentrations $(10,25,50$ and 100 $\mu \mathrm{g} / \mathrm{mL}$ ). After $30 \mathrm{~min}$ in the dark room, the absorbance was measured at $517 \mathrm{~nm}$.

\section{ABTS radical cation decolorization assay}

In order to generate ABTS cation free radicals, ABTS ( $7 \mathrm{mM}$ in $\left.\mathrm{H}_{2} \mathrm{O}\right)$ solution and potassium persulfate $\left(2.45 \mathrm{mM}\right.$ in $\left.\mathrm{H}_{2} \mathrm{O}\right)$ solution were mixed in $2: 1$ ratio by volume and kept at $4{ }^{\circ} \mathrm{C}$ for 
$24 \mathrm{~h}$ in dark. The $\mathrm{ABTS}^{++}$solution was diluted with $80 \% \mathrm{EtOH}$ to an absorbance of $0.7 \pm 0.02$ at $734 \mathrm{~nm} \mathrm{[18].} \mathrm{The} \mathrm{samples} \mathrm{were}$ dissolved in DMSO to various final concentrations. Antioxidant effect of these samples was evaluated by incubating $10 \mu \mathrm{L}$ of sample solution with $190 \mu \mathrm{L}$ of the ABTS solution in a 96-well plate at room temperature, and the optical density at $734 \mathrm{~nm}$ was read using microreader.

\section{Cell culture and viability}

Murine RAW 264.7 cells, a macrophage-like cell line, was purchased from Korean Cell Line Bank and cultured in Dulbecco's modified Eagle's medium (DMEM, Welgene, Daegu, Korea) supplemented with $10 \%$ fetal bovine serum (Gibco BRL, Grand Island, NY, USA), $100 \mathrm{U} / \mathrm{mL}$ of penicillin and $100 \mu \mathrm{g} / \mathrm{mL}$ of streptomycin $(\mathrm{P} /$ S, Gibco BRL, Grand Island, NY, USA) and incubated at $37{ }^{\circ} \mathrm{C}$ in an atmosphere of $5 \% \mathrm{CO}_{2}$. For the cell viability analysis, RAW 264.7 cells were seeded at a density of $5 \times 10^{4}$ cells/well in 96-well plates. After $24 \mathrm{~h}$, fermented and unfermented samples of different concentrations $(10,25,50$ and $100 \mu \mathrm{g} / \mathrm{mL})$ were added to the wells and incubated for additional $24 \mathrm{~h}$. The culture medium was then removed and MTT in phenol red free DMEM (Welgene, Daegu, Korea) was added to a concentration of $0.5 \mathrm{mg} / \mathrm{mL}$. After incubation at $37{ }^{\circ} \mathrm{C}$ for $4 \mathrm{~h}$, the supernatant was removed and the formazan blue formed was dissolved in $100 \mu \mathrm{L}$ of DMSO. Optical density at $575 \mathrm{~nm}$ was determined with a microplate reader.

\section{Nitric oxide assay}

Cells were seeded into 96-well plates at a density of $5 \times 10^{4}$ cells/ well for $24 \mathrm{~h}$. Cells were treated with each of the samples for $1 \mathrm{~h}$, and then with LPS (final concentration, $1 \mu \mathrm{g} / \mathrm{mL}$ ) for $24 \mathrm{~h}$. After $24 \mathrm{~h}$ of incubation, $100 \mu \mathrm{L}$ of the cell supernatant medium was used for NO determination. The NO produced in culture medium was measured by the method of the Griess reaction. Briefly, 100 $\mu \mathrm{L}$ of the cell culture medium was mixed with $100 \mu \mathrm{L}$ of Griess reagent, in which $\mathrm{N} 1$ and $\mathrm{N} 2$ were mixed in a ratio of 1:1 by volume (N1 reagent: $1 \%(\mathrm{w} / \mathrm{v})$ sulfanilamide in $5 \%(\mathrm{v} / \mathrm{v})$ phosphoric acid, N2 reagent: $0.1 \%(\mathrm{w} / \mathrm{v})$ naphthylethylenediamide- $\mathrm{HCl})$, incubated in dark at room temperature for $10 \mathrm{~min}$, and then the absorbance was measured at $540 \mathrm{~nm}$ [19], using a microplate reader.

\section{Reverse transcription polymerase chain reaction (RT-PCR) analysis}

Total RNA was prepared with TRIzol reagent (Ambion, Austin, TX, USA) from LPS-treated RAW 264.7 cells, and stored at -70 ${ }^{\circ} \mathrm{C}$ until used. To synthesize cDNA from RNA, PrimeScript ${ }^{\mathrm{TM}} 1^{\text {st }}$ strand cDNA synthesis kit (Takara, Otsu, Japan) was used. The reverse transcription reaction cocktail $(20 \mu \mathrm{L})$ was incubated at 42 ${ }^{\circ} \mathrm{C}$ for $45 \mathrm{~min}$ and $95{ }^{\circ} \mathrm{C}$ for $5 \mathrm{~min}$. The synthesized cDNA was diluted 20-fold in diethyl pyrocarbonate water. Conventional PCR for target gene amplification using specific gene primers, was performed using Takara Ex Taq kit (Takara). The reaction comprised 30 cycles of $98{ }^{\circ} \mathrm{C}$ for $10 \mathrm{~s}$ (denaturing), $55{ }^{\circ} \mathrm{C}$ for 30 $\mathrm{s}$ (annealing) and $72{ }^{\circ} \mathrm{C}$ for $1 \mathrm{~min}$ (primer extension). The primers was designed as reported previously [20] and were purchased from Bioneer (Daejeon, Korea). The primer sequences were as follows: iNOS sense 5'-CCCTTCCGAAGTTTCTGGCAGCAGC3'; iNOS antisense 5'-GGCTGTCAGAGCCTCGTGGCTTTGG3'; COX-2 sense 5'-CACTACATCCTGACCCACTT-3'; COX-2 antisense 5'-ATGCTCCTGCTTGAGTATGT-3'; $\beta$-actin sense 5'GTGGGCCGCCCTAGGCACCAG-3'; $\beta$-actin antisense 5'-GGA GGAAGAGGATGCGGCAGT-3'; IL-1 $\beta$ sense 5'-CAGGATGAG GACATGAGCACC-3'; IL-1 $\beta$ antisense 5'-CTCTGCAGACTC AAACTCCAC-3'; IL-6 sense 5'-GTACTCCAGAAGACCAGA GG-3'; IL-6 antisense 5'-TGCTGGTGACAACCACGGCC-3'; TNF- $\alpha$ sense 5'-TTGACCTCAGCGCTGAGTTG-3'; TNF- $\alpha$ antisense 5'-CCTGTAGCCCACGTCGTAGC-3'. PCR products of iNOS, COX-2, $\beta$-Actin, IL-1 $\beta$, IL- 6 and TNF- $\alpha$ were electrophoresed in $1.2 \%$ agarose gels and stained with EcoDye ${ }^{\mathrm{TM}}$ DNA staining solution (Biofact, Daejeon, Korea). Image J was used to quantify RT-PCR products.

\section{Western blot analysis}

EtOAc fraction of fermented and unfermented Bat Faeces was added to LPS-treated RAW 264.7 cells as described above. After washing with $1 \mathrm{X}$ PBS, the cells were lysed using Pro-Prep protein extraction solution (iNtRON Biotechnology Inc., Seoul, Korea) to obtain whole cell lysate. Nuclear proteins were extracted using Nuclear Extraction Kit (Abcam, MA, USA). The amount of protein was measured using the BCA protein assay kit (Thermo Fisher Scientific, Waltman, MA, USA). Twenty micrograms of proteins from each sample was mixed with $5 \mathrm{X}$ loading buffer (Biosesang, Sungnam, Korea), boiled for $10 \mathrm{~min}$ and electrophoresed in $10 \%$ sodium dodecyl sulfate polyacryamide gel and transferred to polyvinylidene difluoride membranes. The membranes were blocked with 5\% skim milk in Tris-Buffered Saline and Tween 20 solution, followed by incubation with primary antibodies against

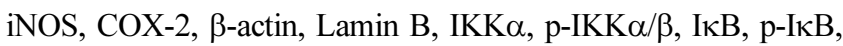
ERK, p-ERK, p38, p-p38 and NF- $\kappa B$. After washing, the membranes were treated with HRP-conjugated secondary antibodies (1:1000) for $40 \mathrm{~min}$. $\beta$-Actin was used as protein loading controls. Bands were detected using ECL kit (Thermo Fisher Scientific, Waltman, MA, USA) and measured with LAS instrument. Image J was used to quantify western blot signals.

\section{Statistical analysis}

All experiments were performed in triplicate. The results were presented as mean \pm standard deviation (SD). Statistical significance was determined using one-way analysis of variance (ANOVA), followed by Tukey's tests. P values less than 0.05 were considered to be significant. 


\section{Results and Discussion}

\section{UPLC patterns of fermented Bat Faeces fractions}

The UPLC profile of activated enzyme-treated Bat Faeces fractions were compared with those from inactivated enzymetreated Bat Faeces fractions. The UPLC chromatogram of each fraction had changing peaks due to the fermentation. Especially, the EtOAc fractions of Bat Faeces had significant new peaks after fermentation (black arrows) (Fig. 1).

\section{Antioxidant effects of EFBF-AF}

Endogenous ROS is generated in the course of metabolic activities as well as on exposure to cytokines, chemotherapeutic agents, ultraviolet radiation, and hyperthermia. ROS can perturb the normal redox balance and shift the cells into a state of oxidative stress [21]. In a recent study, a wide range of spectrophotometric assays have evaluated the antioxidant capacity of substances, using methods such as DPPH and ABTS radical scavenging assays [22]. We investigated the antioxidant effect of EFBF-AF using both of these methods. DPPH in EtOH solvent is a stable, free radical, and the solution is violet in color with strong absorbance at $517 \mathrm{~nm}$. When an antioxidant substance scavenges the DPPH radicals, the color of the solution changes to yellow, and the consequent change in absorbance is a measure of the antioxidant activity of the substance under study [23]. The DPPH radical scavenging activity of EFBF-AF was $60.96 \pm 6.72 \%$ at a concentration of $100 \mu \mathrm{g} / \mathrm{mL}$, while the control (autoclaved enzymetreated Bat Faeces) showed only a negligible effect at the concentration (10.77 $\pm 4.08 \%$ : Fig. $2 \mathrm{~B}$ ), thus indicating that fermentation of Bat Faeces increased the DPPH radical scavenging activity by about 5.7 fold. EFBF-AF also showed higher ABTS radical scavenging effect than the ethyl acetate fraction of Bat Faeces before fermentation (EFBF-BF). In particular, at $100 \mu \mathrm{g} / \mathrm{mL}$, the
ABTS radical scavenging activity of EFBF-AF was $95.40 \pm 0.17 \%$, whereas that of the control (EFBF-BF) was $10.73 \pm 3.79 \%$ (Fig. $2 \mathrm{~F})$. There was no difference between the antioxidant activities of hexane and $\mathrm{BuOH}$ fractions of the fermented Bat Faeces. This data clearly suggests that fermentation enhanced both the DPPH and the ABTS radical scavenging activity of Bat Faeces.

\section{Effects of EFBF-AF on LPS-stimulated NO production in RAW 264.7 cells}

Excess NO results in apoptosis of some cell types, including macrophages [24]. Activated macrophages produce large amounts of NO from L-arginine by iNOS. NO is an important intracellular and intercellular regulatory molecule, involved in multiple biological functions such as macrophage-mediated cytotoxicity, smooth muscle relaxation, and neurotransmission [19]. In the present study, we compared the inhibitory effects of the EtOAc fraction of Bat Faeces before and after fermentation, on the LPS-induced proinflammatory molecules, including NO production [25]. The effect on cell viability of the EtOAc fraction from pre- and postfermentation Bat Faces at different concentrations was investigated using the MTT assay. As shown in Fig. 3A and 3B, EFBF-BF and EFBF-AF did not affect the cell viability at concentrations up to $100 \mu \mathrm{g} / \mathrm{mL}$. Therefore, we used samples between $10-100 \mu \mathrm{g} / \mathrm{mL}$ concentrations in all subsequent experiments. The result for NO production is presented in Fig. 2C. When the RAW 264.7 cells were exposed to LPS, NO levels increased significantly, by $100 \%$ over the control. The EFBF-AF decreased the NO production in a dose-dependent manner, whereas the NO production inhibition activity of EFBF-BF was negligible. EFBF-AF suppressed the NO production by $83.5 \%$ at $50 \mu \mathrm{g} / \mathrm{mL}$, and by $50 \%$ at $100 \mu \mathrm{g} / \mathrm{mL}$, in LPS-stimulated RAW 264.7 macrophages. Based on these data, EFBF-BF and EFBF-AF were used at concentrations of 50 and $100 \mu \mathrm{g} / \mathrm{mL}$, respectively, in subsequent experiments.

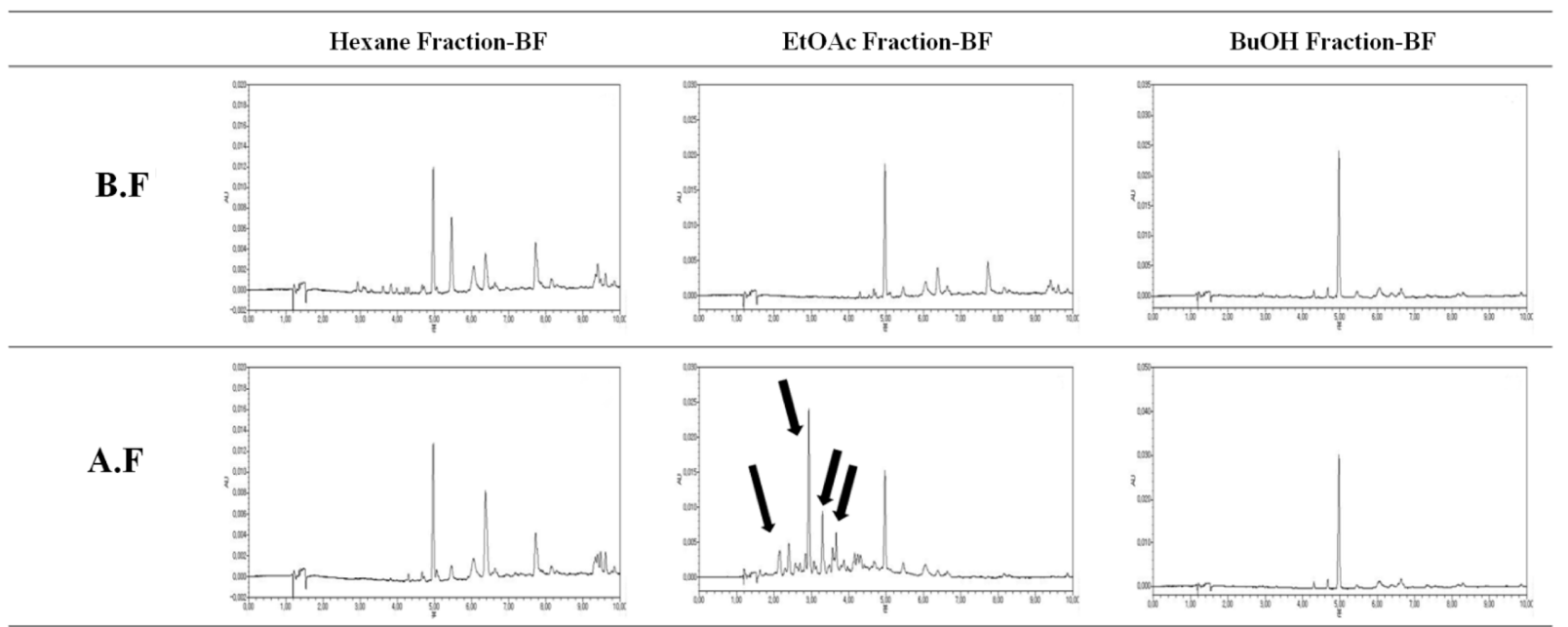

Fig. 1 Comparison of UPLC chromatogram of Bat Faeces before and after crude enzyme extract from A. kawachii treatment. BF, Bat Faeces; B.F, before fermentation (inactivated crude enzyme extract from A.kawachii); A.F, after fermentation (activated crude enzyme extract from A. kawachii). Black arrows represent increased peaks 

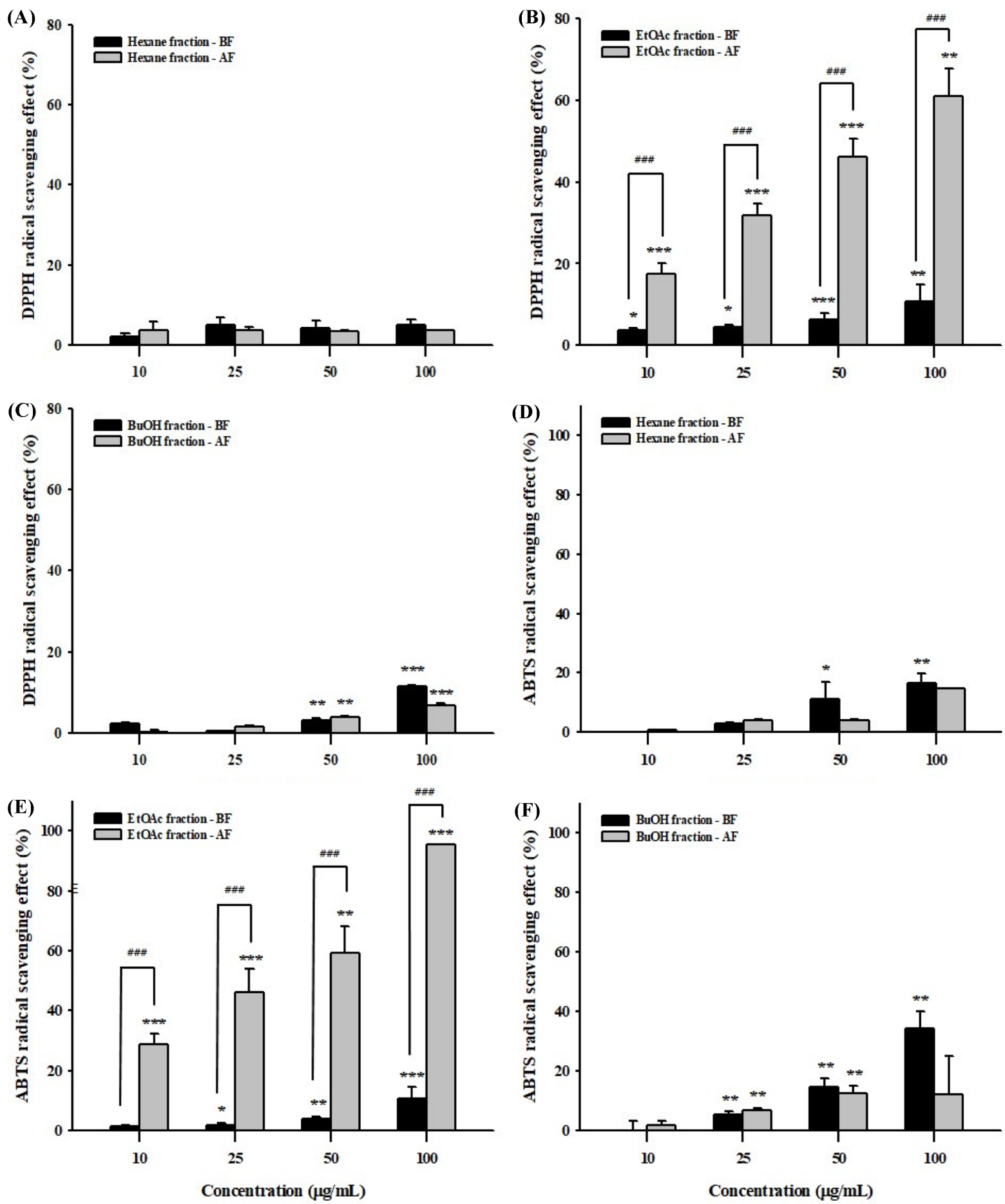

Fig. 2 Antioxidant activity of fractions of Bat Faeces treated with inactivated crude enzyme extract from $A$. kawachii or activated crude enzyme extract from A.kawachii. DPPH radical scavenging effect of hexane (A), EtOAc (B), and BuOH (C) fractions. ABTS radical scavenging effect of hexane (D), EtOAc (E), and $\mathrm{BuOH}(\mathrm{F})$ fractions. $\mathrm{CA}$, crude enzyme extract from A.kawachii; BF, before fermentation (inactivated crude enzyme extract from A. kawachii); AF, after fermentation (activated crude enzyme extract from A.kawachii). Values represent mean $\pm \mathrm{SD}$ of relative OD obtained from three independent experiments. ${ }^{*} p<0.05,{ }^{* *} p<0.01$, and ${ }^{* * *} p<0.001$ compared to control. ${ }^{*} p<0.001$ when compared with fermentation of the EtOAc soluble fraction 

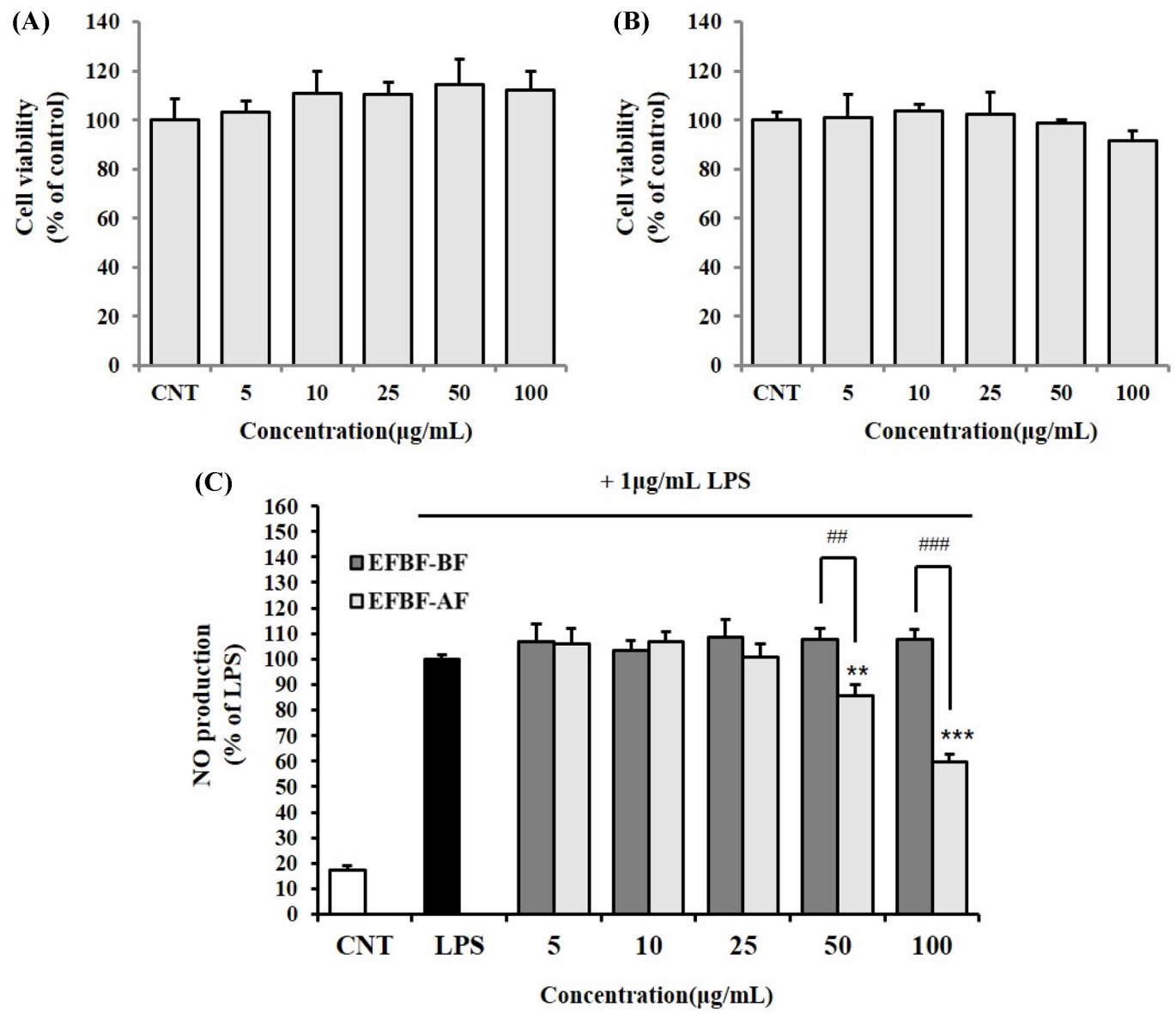

Fig. 3 Effect of EFBF-AF on the viability of RAW 264.7 cells and suppression of LPS-induced NO production. Cultured cells were treated with different concentrations of Bat Faeces EtOAc fraction before (A) and after (B) fermentation to confirm cell cytotoxicity. Cells were pre-treated with 5$100 \mu \mathrm{g} / \mathrm{mL}$ of EFBF-BF and EFBF-AF prior to LPS $(1 \mu \mathrm{g} / \mathrm{mL})$ treatment. Supernatants were collected following $24 \mathrm{~h}$ in culture to determine their NO production (C). EFBF-BF, ethyl acetate fraction of Bat Faeces before fermentation; EFBF-AF, ethyl acetate fraction of Bat Faeces after fermentation. ${ }^{* *} p<0.01$ and ${ }^{* * *} p<0.001$ compared to LPS alone. ${ }^{\#} p<0.01$ and ${ }^{\# \#} p<0.001$ when compared with fermentation of the EtOAc-soluble fraction

Effects of EFBF-AF on LPS-stimulated iNOS and COX-2 expression in RAW 264.7 cells

iNOS and COX-2 are important enzymes that mediate inflammatory processes. Overproduction of iNOS and/or COX-2 has been associated with pathophysiology of certain types of human cancers as well as inflammatory disorders [26]. Expression of iNOS and COX-2 genes increases in response to pro-inflammatory and inflammatory mediators [27]. To investigate the inhibitory effect of EFBF-AF on the mRNA and protein expression of iNOS and COX-2, we performed RT-PCR and western blotting experiments. RAW 264.7 cells exposed to $1 \mu \mathrm{g} / \mathrm{mL}$ of LPS, both with and without pretreatment with the EFBF-BF, showed markedly increased expression of both iNOS and COX-2 expression. However, The EFBF-AF pretreatment significantly suppressed the mRNA and protein levels of iNOS in a dose-dependent manner in LPS-stimulated RAW 264.7 cells, indicating that EFBF-AF reduced the LPS-stimulated NO production by inhibiting the iNOS gene expression at the mRNA and protein levels. Pretreatment with
EFBF-AF also significantly repressed mRNA and protein expression of COX-2 in LPS-stimulated RAW 264.7 macrophage cells (Fig. 4).

\section{Effects of EFBF-AF on LPS-stimulated cytokine expression in RAW 264.7 cells}

Pro-inflammatory cytokines such as IL-1 $\beta$, IL-6, and TNF- $\alpha$, are up-regulated in LPS-stimulated RAW 264.7 macrophage cells [28]. Cytokines are an important cellular defense mechanism, because cytokine production is the first cellular response to a microbial infection $[7,29]$. We investigated whether EFBF-AF has an effect on the production of pro-inflammatory cytokines, including IL-1 $\beta$, IL-6, and TNF- $\alpha$. The expression and secretion of these cytokines in RAW 264.7 macrophage cells were measured using RT-PCR. As depicted in Fig. 4, RAW 264.7 cells incubated with LPS $(1 \mu \mathrm{g} / \mathrm{mL})$ for $24 \mathrm{~h}$ exhibited significantly increased expression of IL- $1 \beta$, IL- 6 , and TNF- $\alpha$ as evaluated by RT-PCR. However, pretreatment with EFBF-AF inhibited the LPS-induced secretion of IL-1 $\beta$, IL-6, and TNF- $\alpha$ in a dose-dependent manner. Conversely, 
(A)
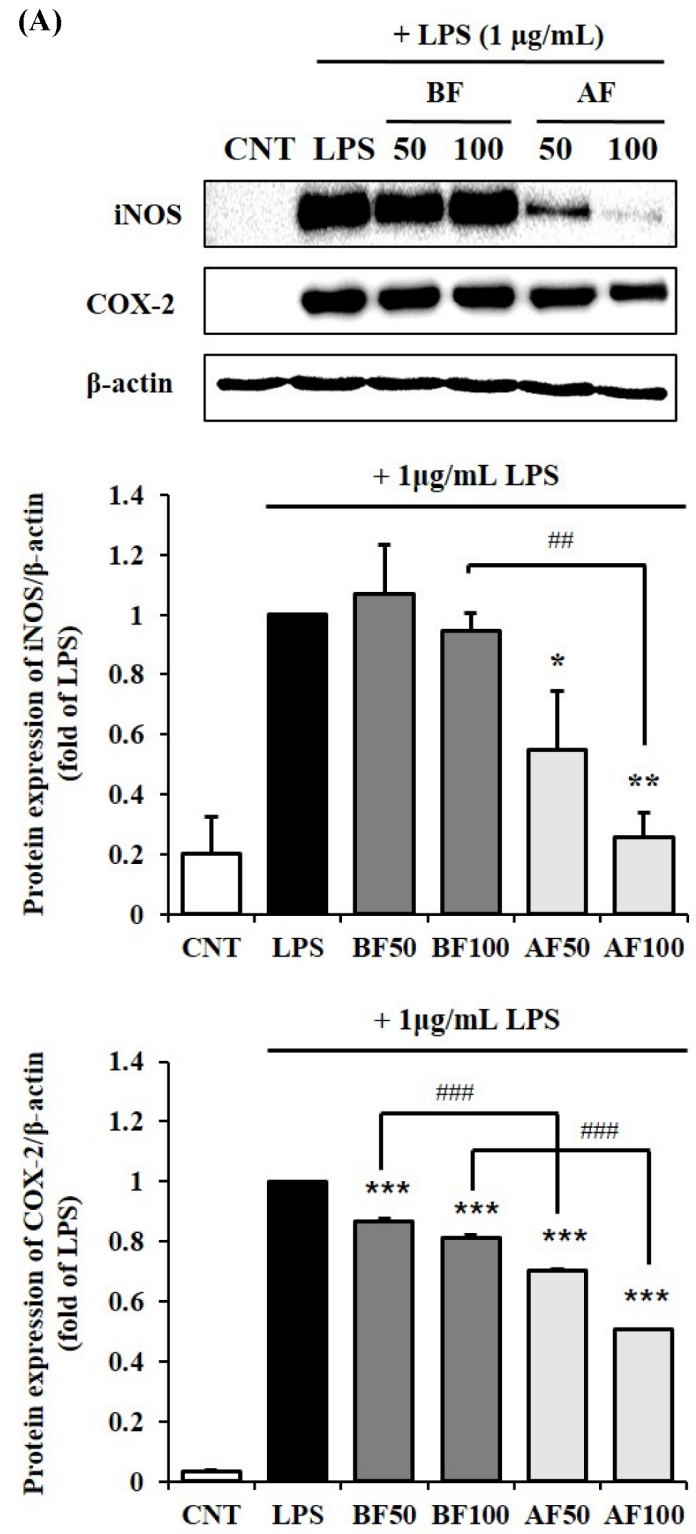

(B)
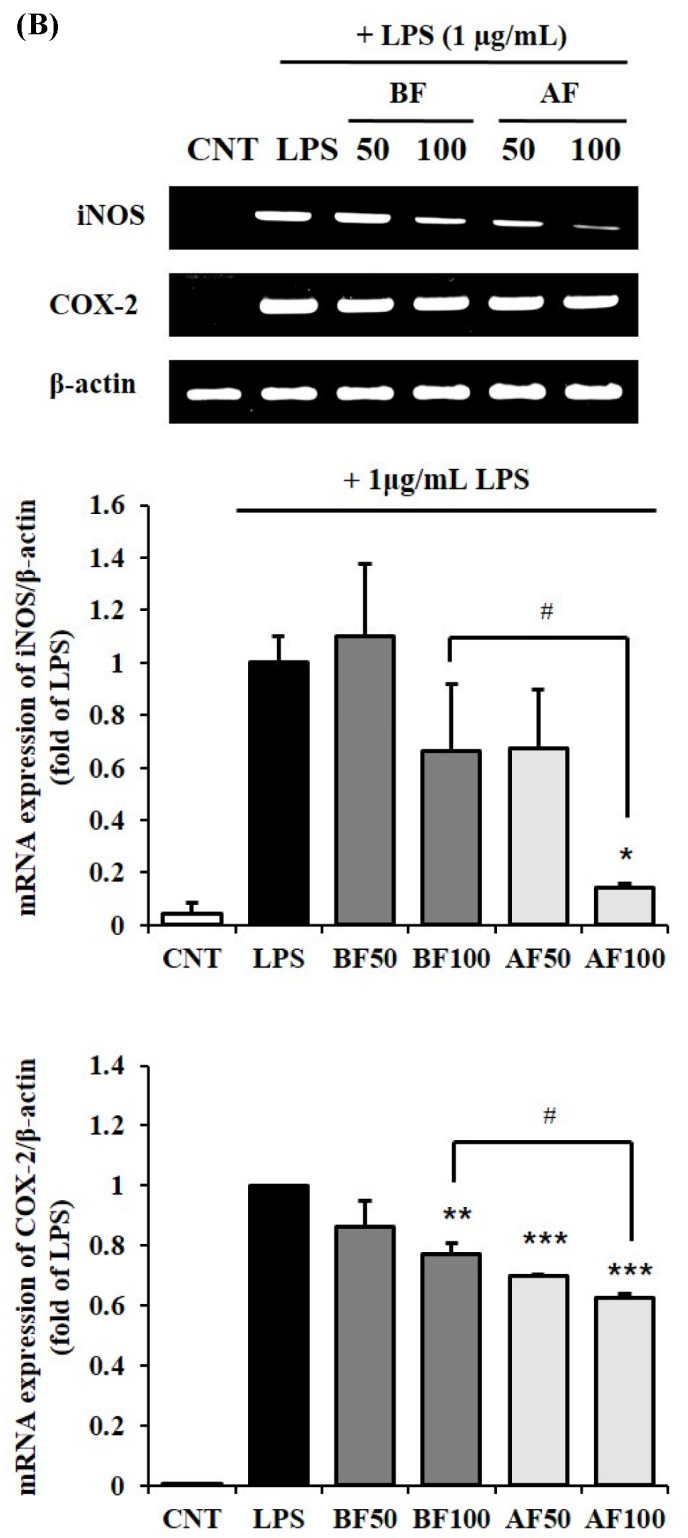

Fig. 4 Inhibition of LPS-induced iNOS and COX-2 protein (A) and mRNA (B) expression by the addition of EtOAc fraction of fermented Bat Faeces to RAW 264.7 macrophage cells. RAW 264.7 cells were pre-treated with EFBF-BF and EFBF-AF $(50,100 \mu \mathrm{g} / \mathrm{mL}$ respectively) for $24 \mathrm{~h}$ prior to LPS $(1 \mu \mathrm{g} / \mathrm{mL})$ treatment. Cellular proteins were used for the detection of iNOS and COX2 by western blotting. mRNA levels of iNOS and COX-2 were then measured using RT-PCR. $\beta$-Actin expression was used as the internal control. CNT, control; LPS, $1 \mu \mathrm{g} / \mathrm{mL}$ of LPS; BF, EtOAc fraction of Bat Faeces before fermentation; AF, EtOAc fraction of Bat Faeces after fermentation. ${ }^{*} p<0.05,{ }^{* *} p<0.01$, and ${ }^{* * *} p<0.001$ compared to LPS alone. ${ }^{\#} p<0.05,{ }^{\# \#} p<0.01$ and ${ }^{\# \#} p<0.001$ when compared with fermentation of the EtOAc-soluble fraction

EFBF-BF showed only a negligible inhibitory effect at the same concentration. These data indicate that EFBF-AF exerts its antiinflammatory effect by the down-regulation IL-1 $\beta$, IL-6, and TNF- $\alpha$ expression (Fig. 5).

\section{Effects of EFBF-AF on LPS-stimulated NF- $\kappa$ B translation in RAW 264.7 cells}

$\mathrm{NF}-\kappa \mathrm{B}$ is a transcription factor that controls various genes, including iNOS, COX-2, IL-1 $\beta$, IL- 6 , and TNF- $\alpha$. The role of
NF- $\kappa \mathrm{B}$ signaling pathways in immunity and inflammation in LPSstimulated RAW 264.7 macrophage cells is well documented [30]. In unstimulated cells, NF- $\kappa \mathrm{B}$ is comprised mainly of proteins $\mathrm{p} 50$ and p65, and is combined with I kappa B (IкB) in the cytoplasm. However, when the cells are treated with LPS, I $\mathrm{B}$ is phosphorylated and detaches from NF- $\kappa B$, resulting in translocation of NF- $\kappa B$ to the cell nucleus [31]. To evaluate whether EFBF-AF was related to the NF- $\kappa B$ signaling pathway, the cells were pre-treated with EFBF-AF for $1 \mathrm{~h}$, followed by LPS treatment for $1.5 \mathrm{~h}$. NF- $\mathrm{kB}$ 
(A)
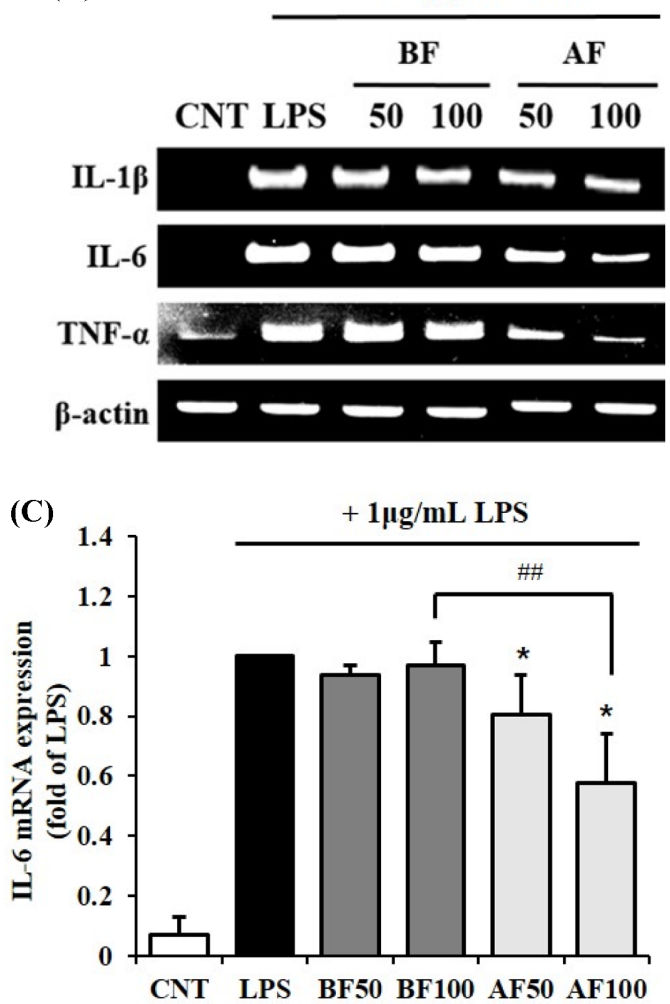
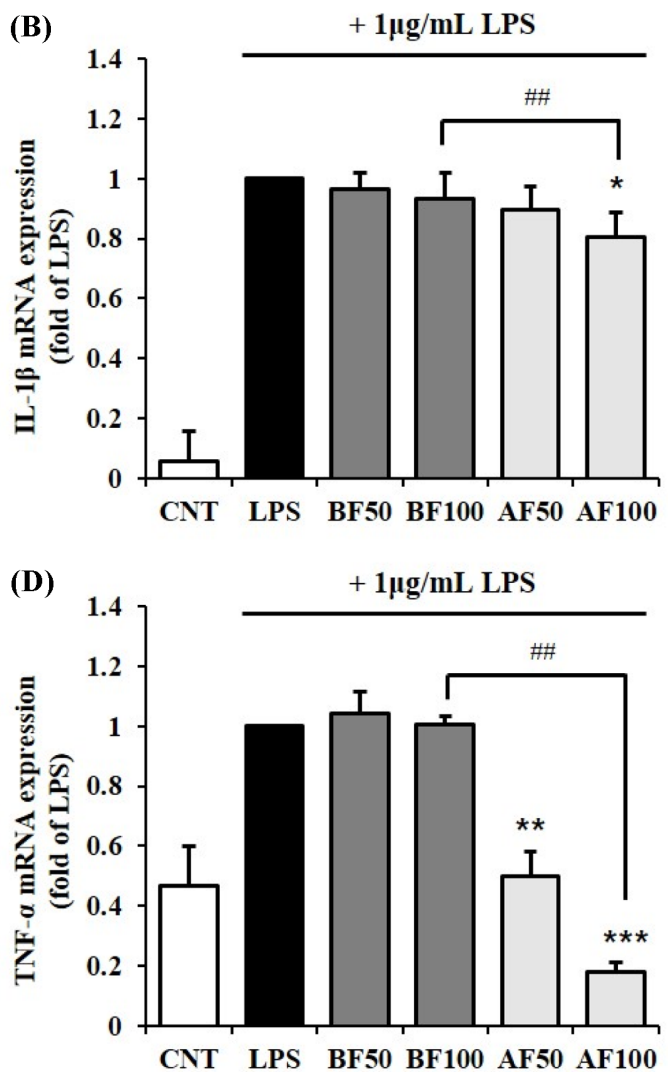

Fig. 5 Inhibitory effect of EFBF-AF on LPS-induced IL-1 $\beta$, IL-6, and TNF- $\alpha$ production in RAW 264.7 macrophages. RAW 264.7 cells were pretreated with EFBF-BF and EFBF-AF $(50,100 \mu \mathrm{g} / \mathrm{mL}$ respectively) for $1 \mathrm{~h}$ and then stimulated with LPS $(1 \mu \mathrm{g} / \mathrm{mL})$ for $24 \mathrm{~h}$. The levels of IL-1 $\beta$ (B), IL-6 (C), and TNF- $\alpha$ (D) mRNA were determined by RT-PCR. Each value is mean \pm SE from three independent experiments. ${ }^{*} p<0.05$, ${ }^{* *} p<0.01$, and ${ }^{* * *} p<0.001$. ${ }^{*} p<0.01$ when compared with fermentation of the EtOAc-soluble fraction

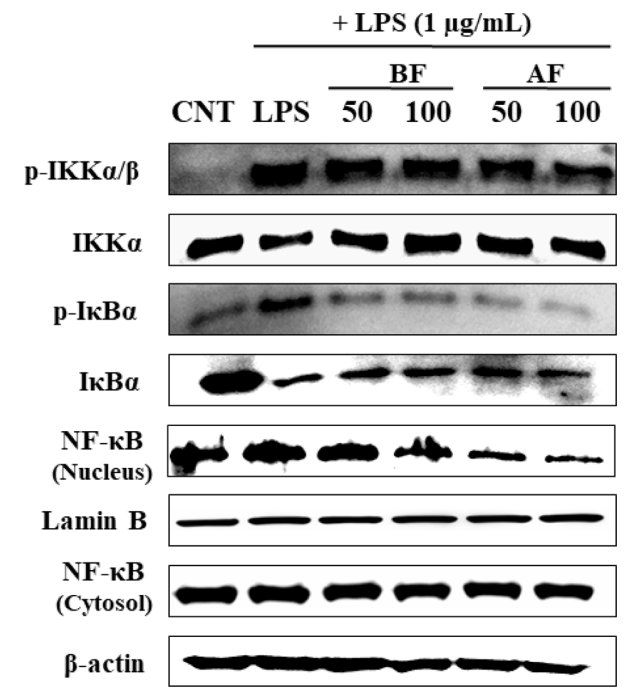

Fig. 6 Effect of the EFBF-AF on the regulation of NF- $\mathrm{BB}(\mathrm{A})$ via IKK $\alpha / \beta$ and I $\mathrm{I} B \alpha$ phosphorylation (B). Nuclear fraction and total cell lysates were prepared for Western blot analysis. RAW 264.7 cells were pre-treated with EFBF-BF and EFBF-AF $(50,100 \mu \mathrm{g} / \mathrm{mL}$ respectively) for $1 \mathrm{~h}$ followed by treatment with LPS for $1.5 \mathrm{~h}$ to detect NF-KB translocation. Cellular proteins were used for the detection of phosphorylated forms of IKK $\alpha / \beta$ and IкB $\alpha$ by western blotting. $\beta$-Actin and Lamin B were used as loading controls.; LPS treatment for $30 \mathrm{~min}$ to confirm phosphorylation of IKK $\alpha$ and IKB $\alpha / \beta$ translocation was observed by western blot analysis. EFBF-AF treatment decreased the nuclear levels of NF- $\kappa B$ p 65 , relative to those in the LPS only treatment and EFBF-BF-treated samples. Translocation of NF- $\kappa \mathrm{B}$ is associated with p-IKK and $\mathrm{p}-\mathrm{I} \kappa \mathrm{B}$ as TLR4 pathway [32]. As shown in Fig. 6, when EFBF-AF treatment preceded the LPS treatment, the phosphorylation of IKK and IKB levels were significantly reduced. Pretreatment of the cells with EFBF-BF showed negligible effect on the phosphorylation of
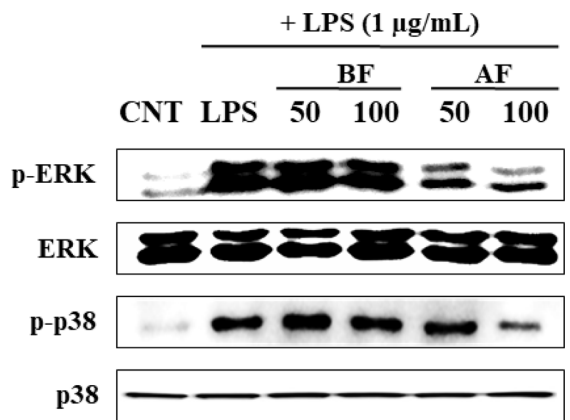

Fig. 7 Effect of the EFBF-AF on phosphorylation of p38 and ERK in LPS-stimulated RAW 264.7 cells. Total protein levels were analyzed by western blot. The cells were incubated with EFBF-BF or EFBF-AF for 1 $\mathrm{h}$ and then exposed to $1 \mu \mathrm{g} / \mathrm{mL}$ of LPS for $24 \mathrm{~h}$ 
these two proteins. These data suggest that fermentation of Bat Faeces extract inhibits NF- $\kappa B$ translocation by regulation of the $N F-\kappa B$ signaling pathway. These results also suggest that the transcriptional down-regulation of the iNOS, COX-2 and several pro-inflammatory mediators, such as TNF- $\alpha$, IL- 6 and IL- $1 \beta$, by EFBF-AF results from an inhibition of the NF- $\kappa B$ signaling pathway.

\section{Effects of EFBF-AF on LPS-stimulated ERK and p38 phosphorylation in RAW 264.7 cells}

The activation and phosphorylation of ERK is an important signaling pathway of inflammation. The MAPKs are also involved in the modulation of iNOS as well as the expression of various cytokines in LPS-induced RAW 264.7 cells [33-35]. The inhibitory effects of the EFBF-AF on LPS-induced ERK and p38 phosphorylation were studied using a western blot assay. The phosphorylation levels of ERK and p38 significantly increased in the LPS-treated RAW 264.7 cells, and the phosphorylation of ERK and p38 were clearly attenuated by the EFBF-AF. These results indicate that the EFBF-AF might partially suppress proinflammatory mediator cytokine expression via ERK and p38 signaling pathways (Fig. 7).

\section{References}

1. Li SX, Deng NS (2003) Speciation analysis of iron in traditional Chinese medicine by flame atomic absorption spectrometry. J Pharmaceut Biomed 32: $51-57$

2. Guo Y, Zou X, Chen Y, Wang D, Wang S (1997) Sustainability of wildlife use in raditional Chinese medicine. Conserving China's Biodiversity 190-220

3. Riccucci M (2012) Bats as materia medica: an ethnomedical review and implications for conservation. Vespertillio 16: 249-270

4. Choe E, Min DB (2005) Chemistry and reactions of reactive oxygen species in foods. J Food Sci 70: R142-R159

5. Suja KP, Jayalekshmy A, Arumughan C (2005) Antioxidant activity of sesame cake extract. Food Chem 91: 213-219

6. Reddy V, Urooj A, Kumar A (2005) Evaluation of antioxidant activity of some plant extracts and their application in biscuits. Food Chem 90: 317-321

7. Rhule A, Navarro S, Smith JR, Shepherd DM (2006) Panax notoginseng attenuates LPS-induced pro-inflammatory mediators in RAW264.7 cells. J Ethnopharmacol 106: 121-128

8. Guha M, Mackman N (2001) LPS induction of gene expression in human monocytes. Cell. Signal 13: 85-94

9. Kim JB, Han AR, Park EY, Kim JY, Cho W, Lee J, Lee KT (2007) Inhibition of LPS-induced iNOS, COX-2 and cytokines expression by poncirin through the NF- $\kappa$ B inactivation in RAW 264.7 macrophage cells. Biol Pharm Bull 30:2345-2351

10. Liu SF, Malik AB (2006) NF- $\kappa B$ activation as a pathological mechanism of septic shock and inflammation. Am J Physiol-Lung C 290: L622L645

11. Cha BJ, Park JH, Shrestha S, Baek NI, Lee SM, Lee TH, Lee DY (2015) Glycosyl glycerides from hydroponic Panax ginseng inhibited NO production in lipopolysaccharide-stimulated RAW264.7 cells. J Ginseng Res 39: 162-168

12. Cho W, Nam JW, Kang HJ, Windono T, Seo EK, Lee KT (2009)
Zedoarondiol isolated from the rhizoma of Curcuma heyneana is involved in the inhibition of iNOS, COX-2 and pro-inflammatory cytokines via the downregulation of NF- $\mathrm{KB}$ pathway in LPS-stimulated murine macrophages. Int Immunopharmacol 9: 1049-1057

13. Kim KN, Heo SJ, Yoon WJ, Kang SM, Ahn G, Yi TH, Jeon YJ (2010) Fucoxanthin inhibits the inflammatory response by suppressing the activation of NF- $\kappa \mathrm{B}$ and MAPKs in lipopolysaccharide-induced RAW 264.7 macrophages. Eur J pharmacol 649: 369-375

14. McFeeters RF (2004) Fermentation microorganisms and flavor changes in fermented foods. J Food Sci 69: 35-37

15. Kim SI, Kim JE, So JH, Rhee IK, Chung SK, Lee KB, Song KS (2004) Changes in chemical composition and biological activities of oriental crude drugs by food processing techniques (I)-changes in liquiritigenin contents in licorice extract treated by crude enzyme extract from Aspergillus kawachii. Kor J Pharmacogn 35: 309-314

16. Yang EJ, Kim SI, Park SY, Bang HY, Jeong JH, So JH, Song KS (2012) Fermentation enhances the in vitro antioxidative effect of onion (Allium cepa) via an increase in quercetin content. Food Chem Toxicol 50: 20422048

17. Yoshiki Y, Kahara T, Okubo K, Sakabe T, Yamasaki T (2001) Superoxideand 1,1-diphenyl-2-picrylhydrazyl radical-scavenging activities of soyasaponin $\beta \mathrm{g}$ related to gallic acid. Biosci Biotech Bioch 65: 2162-2165

18. Re R, Pellegrini N, Proteggente A, Pannala A, Yang M, Rice-Evans C (1999) Antioxidant activity applying an improved ABTS radical cation decolorization assay. Free Radical Bio Med 26: 1231-1237

19. Ranneh Y, Ali F, Al-Qubaisi M, Esa NM, Ismail A (2016) The inhibitory activity of cocoa phenolic extract against pro-inflammatory mediators secretion induced by lipopolysaccharide in RAW 264.7 cells. SpringerPlus 5: 547

20. Heo SJ, Yoon WJ, Kim KN, Ahn GN, Kang SM, Kang DH, Jeon YJ (2010) Evaluation of anti-inflammatory effect of fucoxanthin isolated from brown algae in lipopolysaccharide-stimulated RAW 264.7 macrophages. Food Chem Toxicol 48: 2045-2051

21. Finkel T, Holbrook NJ (2000) Oxidants, oxidative stress and the biology of ageing. Nature 408: 239-247

22. Floegel A, Kim DO, Chung SJ, Koo SI, Chun OK (2011) Comparison of ABTS/DPPH assays to measure antioxidant capacity in popular antioxidant-rich US foods. J Food Compos Anal 24: 1043-1048

23. Brand-Williams W, Cuvelier ME, Berset CLWT (1995) Use of a free radical method to evaluate antioxidant activity. LWT-Food Sci Technol 28: 25-30

24. Gotoh T, Mori M (1999) Arginase II downregulates nitric oxide (NO) production and prevents NO-mediated apoptosis in murine macrophagederived RAW 264.7 cells. J Cell Biol 144: 427-434

25. Kim JW, Kim C (2005) Inhibition of LPS-induced NO production by taurine chloramine in macrophages is mediated though Ras-ERK-NF$\kappa B$. Biochem pharmacol 70: 1352-1360

26. Surh YJ, Chun KS, Cha HH, Han SS, Keum YS, Park KK, Lee SS (2001) Molecular mechanisms underlying chemopreventive activities of anti-inflammatory phytochemicals: down-regulation of COX-2 and iNOS through suppression of NF- $\mathrm{KB}$ activation. Mutat Res-Fund Mol M 480: 243-268

27. Han M, Wen JK, Zheng B, Zhang DQ (2004) Acetylbritannilatone suppresses NO and PGE 2 synthesis in RAW 264.7 macrophages through the inhibition of iNOS and COX-2 gene expression. Life Sci 75: 675-684

28. Hanada T, Yoshimura A (2002) Regulation of cytokine signaling and inflammation. Cytokine Growth F R 13: 413-421

29. Håversen L, Ohlsson BG, Hahn-Zoric M, Hanson LÅ, Mattsby-Baltzer I (2002) Lactoferrin down-regulates the LPS-induced cytokine production in monocytic cells via NF-אB. Cell Immunol 220: 83-95

30. Yun KJ, Kim JY, Kim JB, Lee KW, Jeong SY, Park HJ, Lee KT (2008) Inhibition of LPS-induced NO and PGE 2 production by asiatic acid via NF- $\kappa$ B inactivation in RAW 264.7 macrophages: possible involvement of the IKK and MAPK pathways. Int. Immunopharmacol 8: 431-441 
31. Sung MJ, Davaatseren M, Kim W, Park SK, Kim SH, Hur HJ, Kwon DY (2009) Vitisin A suppresses LPS-induced NO production by inhibiting ERK, p38, and NF- $\mathrm{kB}$ activation in RAW 264.7 cells. Int Immunopharmacol 9: 319-323

32. Oh WJ, Jung U, Eom HS, Shin HJ, Park HR (2013) Inhibition of lipopolysaccharide-induced proinflammatory responses by Buddleja officinalis extract in BV-2 microglial cells via negative regulation of NF$\kappa \mathrm{B}$ and ERK1/2 signaling. Molecules 18: 9195-9206

33. An H, Yu Y, Zhang M, Xu H, Qi R, Yan X, Qin Z (2002) Involvement of ERK, p38 and NFêB signal transduction in regulation of TLR2, TLR4 and TLR9 gene expression induced by lipopolysaccharide in mouse dendritic cells. Immunology 106: 38-45

34. Chen JC, Huang KC, Lin WW (2006) HMG-CoA reductase inhibitors upregulate heme oxygenase-1 expression in murine RAW264.7 macrophages via ERK, p38 MAPK and protein kinase $G$ pathways. Cellular signaling 18: $32-39$

35. Kim YS, Ahn CB, Je JY (2016) Anti-inflammatory action of high molecular weight Mytilus edulis hydrolysates fraction in LPS-induced RAW264.7 macrophage via NF- $\mathrm{B}$ and MAPK pathways. Food Chem 202: 9-14 